\title{
Tax Reforms in Selected Balkan Countries: The Case Study of Kosovo
}

\author{
Bedri Peci ${ }^{1}$ \\ ${ }^{1}$ Department of Financial Law, Faculty of Law, University "Hasan Prishtina”, Prishtine, Republic of Kosovo. \\ Correspondence: Dr. Sc. Bedri Peci, Associate Professor, Department of Financial Law, Faculty of Law, University \\ "Hasan Pristina", Str. "Mother Teresa",10 000 Prishtinë, Republic of Kosovo.
}

Received: August 2, 2016

Accepted: August 16, 2016

Available online: August 26, 2016

doi:10.11114/aef.v3i4.1783

URL: http://dx.doi.org/10.11114/aef.v3i4.1783

\begin{abstract}
The aim of this research is to analyze and find out the major issue of tax reforms in selected Balkan Countries and the case of Kosovo. In this analysis we have used the research method of case study. The results of research show that reforms of tax systems of Balkan Countries, including Kosovo, is one of the most important components of their social-economic transition led by the aspiration to become members of the European Union. Higher results consist in the fact that the Balkan countries, some earlier some later, have included Personal Income Tax, Corporate Income Tax and the VAT into their tax systems. In this context, in order to create competitive tax systems to attract investments and to make tax harmonization with the EU, the tax rates have considerably been reduced and successful steps have been taken in the function of harmonization of taxes with the EU member countries. Some countries have managed to build their tax systems in accordance with acquis communautaire. After the declaration of Independence, the Government of the Republic of Kosovo took the first reformation step by reducing the income and corporation income tax rates. However, the taxation system and policies in Kosovo must also be reformed in many other components. Today, when from the start of transition process in the Balkan countries about 26 years have passed, the reformation of their tax system is still ongoing, facing numerous challenges.
\end{abstract}

Keywords: reform, tax system, transition, Balkan countries, harmonization, tax structure.

\section{Introduction}

After the fall of communist systems in the Balkan countries, in quite specific circumstances, the process of reformation of taxation systems within the framework of the social-economic transition started as a whole. Transition as a concept is a transforming process of deep dimensions of a social-economic system, by means of which this system passes into a new structure, which provides a higher efficiency and effectiveness. Thus, the Balkan states, in order to achieve these performances, had to make changes in all their subsystems of the social- economic system, in the first place in the political system, in the economic system, in the education system, etc.

Based on this, the transitional measures of the economic policy in these countries, in general, were, first of all, directed to liberalization of prices and market, public finance sustainability and development (tax and budget reforms),currency credibility, enterprise restructuring, enterprise privatization, creation of social insurance network and market oriented economies, legal and institutional framework development, etc. However, in order to remain faithful to the analysis object of this study, we shall, in the following, focus only on the tax reforms in the selected Balkan countries: Albania, Bulgaria, Croatia, Macedonia, Romania, and laying a special emphasis on Kosovo.

When in the early 90s the transition process in the European South-eastern countries began, the economic sciences were not so familiar with such practices of taxation reforms, which would help the bearers of economic policies. Gradually and upon becoming familiar with the first experiences of some countries in transition, many scientists got down to the analyses of taxation reforms processes. It has to be emphasized that the property changes, the building of democratic institutions, the problem of economic sustainability and of monetary policy have more been an object of analyses and discussions than tax reforms. The reformation of tax systems constituted only one of the main components of the reforming process within the social- economic transition. An analysis of the process of tax reforms in the Balkan countries was followed not by little difficulties for different authors, not excluding from this environment the author of this work either. On this occasion, from my part, I would highlight the following:

Firstly, that a complete and sustainable analysis is to be based on reliable facts from a reliable source, taking into 
account the nature of cases of reform studies in some countries and the long period of their time extension. The problem with reliable data has particularly been expressed in the first years of transition in all the Balkan countries and it still continues to be true.

In the case of Kosovo, the lack of a national office of statistical data of economic indicators was a big problem, which also had direct effects on the tax reform. The creation of the fiscal policy by UNMIK was done in quite specific conditions in comparison with other countries. This is due to the fact that the fiscal charge was applied in the absence of an economic development strategy, as well as in the absence of definition and formulation of a long-term consistent fiscal policy. This absence was as a result of non- definition of the political status of Kosovo and of a sui generis model of administration by UNMIK, which applied the fiscal policy only in the function of accomplishment of fiscal objectives. Thus, the fiscal charge in Kosovo was applied by UNMIK in the absence of a real determination of macro-economic factors, such as GDP, per capita income, etc. The analyses of macroeconomic performances of Kosovo are limited due to a very poor statistical base and frequent changes in the evaluation of macroeconomic processes by the local and international institutions.

Secondly, that the transition process from a centralized economy plan to market economy was accompanied with a great growth of the informal economy sector, which could never be covered by statistics. In the case of Kosovo, the informal economy sector is a terra nullius (waste land) in the sense of institutional recognition and measurements. No one has so far made a real statistical analysis.

Thirdly, that the public sector, which includes a great number of data in itself, is difficult to compare and harmonize for study cases. Often, these data differ from an institution to another, within a country, all the more within countries.

In this study we have used the research method of case study, based on theoretical and empirical data. Furthermore, the methodology of the research is based on different papers which talked about transition countries, on IBFD surveys, IMF reports, etc. For comprehensive purposes the analysis of Kosovo case was made based on different papers which talked about tax reforms on transition countries, as well on other secondary sources.

This study aims to develop a comparative analysis among tax systems and their reforms in Balkan Countries and harmonization process that took place during the EU accession process. Therefore, the aim of this analysis is highlighting some of basic specifics which characterize policy and tax systems reforms in selected Balkan Countries and Kosovo case. In addition to this introduction the paper deals four main parts. In the first part the tax reforms background in selected Balkan countries is presented. The second part contains analysis of the tax system and reform background in Kosovo. In the third part, we have treated the main characteristics of tax reform trends in the selected Balkan countries with special emphasis on the case of Kosovo, whilst in the fourth part the tax harmonization, as a motive and trend of taxation reforms in the Balkan countries, has been analysed. The analysis ends with a summary of conclusions and recommendations.

\section{Tax Reforms Background In Selected Balkan Countries}

The designing of an appropriate and functional tax reform has not been an easy objective to be reached in any of the Balkan countries. Difficulties have especially arisen in making the reforms acceptable and then successfully implementable. The taxation reforms management has been during the whole taxation reform process, from the inspection of the state until now, a long and complicated process and it still continues to be.

This is due to the fact that all post-communist countries possessed tax systems drafted for the planned economy and incompatiblewith the market economy and with a tax administration which needed a complete reorganization for the purpose of a successful operation in new conditions (Grabowski, 2004, p.251-301).

The economic transition brought new and unique challenges to the Balkan countries. Some of them we have treated below:

1) In the '90s, the tax systems of post-communist countries were undeveloped. They were characterized by: 1) non-transparency, 2) differences in tax charges by means of which the discrimination of certain activities and factors and at the same time favouring of the others was done:3) there was no balance between direct and indirect taxes; 4) the frequent changes in taxation systems and in certain taxes(especially on the turnover rates) as a consequence of an unsustainable tax policy: 5) complex administrative procedures: 6) incompatibility with the tax systems of West European countries; 7) non-flexibility and non- simplicity (Tanzi, 2002, chapters 5-11,).

2) An indispensable condition (conditio sine qua non) for each tax reform was the tax administration organization. The tax income (revenues) that these countries generated in the past did not indicate what to collect in the future. The incomes were manly transfers from some public sectors, mainly from state owned enterprises. The taxpayer's number (state owned enterprises) was only in thousands and they were easy to be controlled.

The transformation of these economies brought (1) an increase of taxpayers number from thousands to millions, (2) by 
the liberalization of prices and increase of goods turnover, the possibility for tax administration information was limited (reduced), (3) the stimulation of services and activity of small enterprises caused an increase of total income, which was difficult to be taxed by the tax administration (Tanzi, 1993, p.18).

These were only some of the causes that made that almost all the countries in transition to start the real organization of tax administration (Jantscher, Milka, Silvani and Vehorn, 1992, p.120-141). In this context, in the Balkan countries too, the reorganization of tax administration was carried out within the Ministry of Finances and this process is still ongoing. In the process of tax administration organization, an important place had to be given to the preparation of tax reviewers, intensifying taxpayers, taxpayer's assistance, etc.

3) The lack of clear economic strategies. In none of the Balkan country was there a clear institutional strategy for the transition process. The more the economies of these countries were centralized, the more difficult was the choice of the institutional system based on which tax reforms would be conducted.

4) A similar situation in the tendency for the harmonization of their tax systems with the European Union countries $(E U)$. All the Balkan countries have expressed their aspirations for membership in the EU. This was the reason why the Balkan countries have implemented VAT in their tax systems, the corporation income tax with accounting standards, income tax, and customs tariffs ad valorem and excise tax.

5) Tax competition. In this sense the situation was challenging for the Balkan countries. The need of the Balkan countries for investments by foreign investors required the necessity of a competitive approach in designing their tax policies taking a lways into account the importance that the tax policies have in attracting foreign investments through facilities and low tax rates.

6) Low tax education. The countries in transition have operated in environments where the tax payment in the society was not accepted as a kind and usual thing. This was the reason why the evasion was so high.

\section{Tax Reforms Background In the Kosovo Case}

In the long historical context, the policy and tax systems of Kosovo were followed during their evolution by many changes that were made based on the challenges of the political and socio-economic structure of Kosovo (initially as part of a federal system and later following the deployment of the United Nations Interim Administration Mission in Kosovo (the UNMIK). The first phase covered a long time period, including the years from 1945 until the dissolution of the former Yugoslavia in the 1990s. The second phase included the period from the 1990s up to the deployment of the UNMIK in 1999. The third phase runs from 1999 until the Kosovo declaration of independence on 17 February 2008. The fourth phase runs from 2008 onwards the future time perspective.

Kosovo, in distinction to other Balkan countries, made the economic transition, including tax reforms, under the influence of quite specific political factors and circumstances . Reformation of tax system constituted only one of the main components of the reforming process within the social-economic transition. The transition process, which in early '90s encompassed many countries of South-eastern Europe, found Kosovo initially in a situation of an undeclared war, which broke out in 1998 and ended by the Kumanovo Agreement (Military Technical Agreement) on 10 June 1999. On 10 June 1999, the UN Security Council approved Resolution 1244, by which United Nations Administration Mission in Kosovo (UNMIK) was created and therewith the sovereignty of the SFRY over Kosovo was abolished. Until final status settlement (2008), resolution 1244 vested UNMIK with legislative, judicial and executive powers. Upon UNMIK installation in Kosovo, the Central Fiscal Authority in cooperation with World Bank, the European Commission and the International Monetary Fund, started the work in formulation of measures and strategy for creating an efficient tax system in the spirit of the overall economic and social development of Kosovo. The creation of the policy and tax system in Kosovo by UNMIK is a sui generis case, as it was created in practice without any internal influence and without a political dialogue of Kosovar actors (Peci, 2013, p.71).

The highest authority of the fiscal power in Kosovo from 1999 to the Declaration of independence of Kosovo, on 17.02.2008, was the Special representative of the Secretary General (SRSG) of the UN together with the Fiscal Economic Council as an advisory body to the SRSG for fiscal policy issue.

After proclamation of independence, the fiscal sovereignty moves from UNMIK to the Kosovo Institutions, respectively in the Parliament of Kosovo, as the greatest taxing power in applying taxes through tax laws. In this way, Kosovo institutions inherited a policy and tax system designed from UNMIK, which mainly had fiscal functions. This, due to the fact that the main objective of policy and tax system was gathering funds for financing foreseen public costs, by not giving importance to the economic and social functions which can be achieved through policy and tax system. So, policy and tax system inherited by UNMIK had a very limited function vis-à-vis socio-economic needs of Kosovo and trends of taxing competition in Balkan countries. In such a situation, designers of tax policy of independent Kosovo were forced to consider the reformation of system and tax policy. 


\subsection{The Main Characteristics Tax Reforms in Selected Balkan Countries and The Case of Kosovo}

The Balkan states, in distinction to other European countries, made the economic transition, including tax reforms, under the influence of quite specific political factors and circumstances. In this context, two things were the most determining: military conflicts that had captured these countries and the lack of a near prospective for adhering to the EU in those years. Here should be specified Kosovo and Bosnia and Hercegovina, where the political situation influenced directly designation of the tax system and policy. However, every Balkan country, involved in making a tax reform, went through a special path, different from another country. Each tax reform in each country, therefore, bore in itself certain features. However, the trends were common. In this context, all the Balkan countries in different years applied VAT, corporate income tax, and personal income tax in their tax systems.

In the process of tax systems reformation, among other things, two trends should be distinguished: 1) the trend of reduction of the main tax rates with a special emphasis on corporate income tax, and 2) the aspirations and acts of all the Balkan countries for membership in the EU, making the adoption of EU rules.

The Balkan countries, similar to the EU countries and other states of South-eastern Europe, constantly reformed their tax systems by reducing the rates, redefining the tax basis, and doing amendments and clarifications of the existing laws interpretation.

Parallel to the reduction of tax rates, the reduction of tax deductions and exemptions, as counter-reimbursement for the tax rates reduction, was done. In this sense, in the following table we have presented the tax rates reformation in the selected Balkan countries and Kosovo case.

Table 1.The main changes in personal income tax rates, corporate income tax rates and VAT in the Balkan countries from 1992-2016.

\begin{tabular}{|c|c|c|c|}
\hline Country & Personal Income Tax & Corporate Income Tax & Value Added Tax \\
\hline Albania & $\begin{array}{l}\text { Preliminary } 6 \text { rates -from } 5 \% \text { to } \\
30 \% \text {. From } 1 \text { January } 2014, \\
\text { gross monthly salaries and other } \\
\text { remuneration in connection with } \\
\text { employment are taxable at the } \\
\text { following progressive rates; } 0 \% \\
\text { (of the amount under Albanian } \\
\text { Lek (ALL) 30,000),- } 13 \% \text { (of the } \\
\text { amount over ALL 30,000),- ALL } \\
13,000 \text { plus } 23 \% \text { of the amount } \\
\text { over ALL 130,000. }\end{array}$ & $\begin{array}{c}\text { The profit tax is levied at a } \\
\text { rate of } 15 \% \text {. Before } 2014 \text {, } \\
\text { the rate was } 10 \% \text {. }\end{array}$ & $\begin{array}{l}\text { The standard rate of VAT is } \\
20 \% .\end{array}$ \\
\hline Bulgaria & $\begin{array}{l}\text { 1992: } 6 \text { rates } 20 \%, 24 \%, 28 \% \text {, } \\
32 \%, 36 \% \text { and } 40 \% \text { 2002:4 rates } \\
\text { from } 20 \% \text { to } 40 \% \text { : since } 2008 \text { flat } \\
\text { rate ( } 10 \% \text { in general) } \\
\text { flat rate ( } 15 \% \text { for sole traders) }\end{array}$ & $\begin{array}{l}\text { 2000: the rate } 25 \%, 20 \% \text { for } \\
\text { small businesses, } 2002 \text { : the } \\
\text { rate } 23.5 \% \text { then it was } 15 \% \text {, } \\
\text { whilst since } 1 \text { January } 2007 \\
\text { it is } 10 \% \text {. }\end{array}$ & $\begin{array}{l}\text { 1994: the rate } 22 \%, 1999: \\
\text { standard rate is } 20 \% \text {. A } \\
\text { reduced rate of } 9 \% \text { applies } \\
\text { for hotel accommodation }\end{array}$ \\
\hline Croatia & $\begin{array}{c}\text { 1994:00:00 2001:3 rates } 15 \% \text {, } \\
\text { 25\%,35\% 2003: additional rate } \\
\text { 45\%\%; From } 1 \text { January } 2011 \text { (but } \\
\text { applied in respect of withholdings } \\
\text { from } 1 \text { July 2010) to } 29 \text { February } \\
2012 \text { the following progressive } \\
\text { rate structure applied } \\
\text { 12\%,25\%,40\%:For the period } 1 \\
\text { March } 2012 \text { to } 31 \text { December } \\
\text { 2012, the following progressive } \\
\text { rate structure applied } 12 \%, \\
22.83,25 \%, 37.5 \%, \text { and } 40 \%: \\
\text { From } 1 \text { January } 2013, \text { the } \\
\text { following progressive rate } \\
\text { structure applies: } 12 \%, 25 \%, 40 \% \text {. }\end{array}$ & 1994: the rate $20 \%$ & $\begin{array}{c}\text { 1998- The rate } 22 \%, 0 \% \text { : } \\
\text { Currently the standard rate is } \\
25 \% . \text { Reduced rate } 5 \% \text { and } \\
13 \%\end{array}$ \\
\hline
\end{tabular}




\begin{tabular}{|c|c|c|c|}
\hline Macedonia & $\begin{array}{c}\text { Earlier } 2 \text { rates: } 15 \% \text { and } 18 \% \text {, } \\
\text { 2002; rates from } 0 \% \text { to } 38 \% \text {; then } \\
\text { there were progressive rates } \\
15 \%, 18 \% \text { and } 24 \% \text {; from } 1 \\
\text { January } 2007 \text { to } 1 \text { January } 2008 \text { it } \\
\text { was } 12 \% \text {, whilst from } 1 \text { January } \\
2008 \text { is } 10 \% \text { flat rate. }\end{array}$ & $\begin{array}{c}\text { Earlier } 30 \% \text {; then } 15 \% \text {; } \\
2007 \text { it was reduced to } 12 \% \text {; } \\
\text { in } 2008 \text { it was reduced to } \\
10 \% \text { as much as it is } \\
\text { currently }\end{array}$ & $\begin{array}{l}\text { 2000: the rate } 19 \% \text {, } \\
\text { reduced rate } 5 \% \text { for food } \\
\text { products for humanitarian } \\
\text { purposes, agricultural tools } \\
\text { and mechanisms, books. } \\
\text { Currently the standard VAT } \\
\text { rate is } 18 \% . \text { The reduced } \\
\text { VAT rate of } 5 \% \text { applies to } \\
\text { the supply of specific goods } \\
\text { and services. }\end{array}$ \\
\hline Romania & $\begin{array}{c}2003: 5 \text { the rates: } 18 \%, 23 \% \text {, } \\
28 \%, 34 \% \text { and } 40 \% \text {; currently } \\
16 \% \text { flat rate }\end{array}$ & $\begin{array}{c}2003 \text { : the rate } 25 \% \text { (earlier } \\
38 \% \text { ) currently is } 16 \%\end{array}$ & $\begin{array}{l}\text { 1993: the rate } 22 \% \text { and } 11 \% \\
\text { reduced rate; } 2003: \text { the rate } \\
19 \% \text { and } 9 \% \text { reduced rate. } \\
\text { Currently, } 20 \% \text { standard rate } \\
0 \%, 5 \%, 9 \% \text { (there are more } \\
\text { reduced-rated supplies) }\end{array}$ \\
\hline Serbia & $\begin{array}{c}\text { progressive; } \\
\text { top rate } 15 \% \text { (over RSD } \\
4,370,976)\end{array}$ & $\begin{array}{l}\text { Preliminarily: } 20 \%-30 \% \text {; } \\
\text { 2003: the rate was } 14 \% \text {; } \\
\text { since } 1 \text { January } 2013 \\
\text { corporate income tax is } \\
\text { levied at a rate of } 15 \% \text {. }\end{array}$ & $\begin{array}{l}\text { Preliminarily the sale tax } \\
\text { with rates } 20 \% \text {, exempted } \\
\text { public utilities and some } \\
\text { food: from } 2005 \text { it is applied } \\
\text { VAT by } 3 \text { rates: } 18 \%, 8 \% \\
\text { and } 0 \% \text { for medicines, } \\
\text { books. Currently, the } \\
\text { standard rate of VAT is } 20 \% \\
\text { (18\% before } 1 \text { October } \\
\text { 2012). Reduced rates } 0 \% \text {, } \\
10 \%\end{array}$ \\
\hline Montenegro & $\begin{array}{c}\text { Preliminarily the fixed rate } 14 \% \\
\text { of tax on earned income: from } \\
\text { other income the rate of } 10 \%, \\
15 \% \text { and } 20 \% \text {. Currently standard } \\
\text { rate } 9 \%\end{array}$ & $\begin{array}{l}\text { Preliminarily rates: } 20 \% \text {, } \\
\text { 30\%; 2003: the rate } 14 \% \text {. } \\
\text { Currently } 9 \% \text { flat rate; } \\
\text { employment income: } 13 \% \\
\text { flat rate for income over } \\
\text { EUR } 720 \text { per month }\end{array}$ & $\begin{array}{c}\text { From } 1 \text { July } 2013 \text { the } \\
\text { standard rate of VAT is } 19 \% \\
\text { (17\% before that date). } \\
\text { Reduced rates } 0 \%, 7 \%\end{array}$ \\
\hline Kosovo & $\begin{array}{c}\text { 2002: } 4 \text { rates } 0 \%, 5 \%, 10 \% \text { and } \\
\text { 20\%; since } 1 \text { January } 2009 \\
\text { reduced progressive rates } 0 \%, \\
4 \%, 8 \% \text { and } 10 \%\end{array}$ & $\begin{array}{l}\text { 2002: } 20 \% \text { rates for big } \\
\text { companies and of course for } \\
\text { small business: since } 1 \\
\text { January } 2009,10 \% \text { for } \\
\text { companies with gross } \\
\text { income over EUR 50,000 } \\
\text { (for companies with income } \\
\text { below EUR 50,000, the } \\
\text { system is scheduler, } \\
\text { although they may opt for a } \\
10 \% \text { rate) }\end{array}$ & $\begin{array}{l}\text { 2001: } 15 \% \text { and } 0 \% \text {, some } \\
\text { exemptions; } 2002 \text { - reduction } \\
\text { for registration in turnover } \\
\text { above } 50.2000 \text { euro; since } 1 \\
\text { January } 2009 \text { rates until } \\
\text { September } 201516 \% \text { and } \\
\text { 0\%. Since } 1 \text { September } \\
\text { 2015, standard rate } 18 \% \text {. } \\
\text { Reduced rates } 0 \%, 8 \%\end{array}$ \\
\hline
\end{tabular}

Source: Prepared by author according to Mitra, P. \& N. Stern, Tax systems in Transition, WPS 2947, 2003; Kwang-Yeol Yoo, Corporate Taxation of Foreign Direct Investment Income 1991-2001, OECD, ECO/WKP(2003) 19, Tesche, J. The Role of the State in South East Europe - Fiscal Issues, mimeo, US Treasury; VAT rates applied in the member and accession states of the European Community, DOC 2402/2003 EN, - cited by Grabowski M., Tomalak M., (2004). Tax system Reforms in the Countries of the Central Europe and the CIS", Special Study, pp.279, Retrieved from http://www.warsawvoice.pl/krynica2004/special\%20study.pdf; Peci, Peci, Bedri, (2011). Tax Incentives as Important Segment of Tax Reforms in Balkan Countries and Kosovo, Academic Journal -Yearbook Faculty of Law of University of Sarajevo, Vol. 54, p245-269; 2009 Index of Economic Freedom, February 2009; Albania - Country Key Features,Country Key Features IBFD (accessed 31 July 2016). Retrieved from http://online.ibfd.org/document/kf_al; 
Bulgaria-Country Key Features IBFD (accessed 31 July 2016). Retrieved from http://online.ibfd.org/document/kf_bg; Croatia - Key Features IBFD (accessed 31 July 2016). Retrieved from http://online.ibfd.org/document/kf_hr; Macedonia (FYR) - Key Country KeyFeatures, IBFD (accessed 31 July 2016).Retrieved from Retrieved from http://online.ibfd.org/document/kf_mk; Romania - Country Key Features IBFD (accessed 31 July 2016). Retrieved from http://online.ibfd.org/document/kf_ro; Serbia - Key Country Key Features IBFD (accessed 31 July 2016), Retrieved from http://online.ibfd.org/document/kf_rs; Montenegro - Country Key Features IBFD (accessed 31 July 2016),Retrieved from http://online.ibfd.org/document/kf_me; Kosovo-Country Key Features IBFD (accessed 31 July 2016), Retrieved from http://online.ibfd.org/document/kf_k1.

The table show that the main orientation of tax reforms in Balkan countries was reduction of tax norms and that this was made mainly aiming at attracting foreign investors, respectively to create a competitive taxing system in Balkan region.

The comparison of CIT norms of Serbia, Montenegro, Macedonia, Albania, Kosovo and Bosnia \& Herzegovina, with average norms of EU CIT, we might say that Balkan countries have lower norms and that low norms of CIT can be qualified as tax incentive. At Kosovo case, after proclamation of independence, the fiscal sovereignty moves from UNMIK to the Kosovo Institutions, respectively in the Parliament of Kosovo, as the greatest taxing power in applying taxes through tax laws. In this way, Kosovo institutions inherited a policy and tax system designed from UNMIK designer of tax policy. In December 2008, the Government of the Republic of Kosovo took the first steps in changing the tax system inherited from the UNMIK. The measures that were taken are only related to reducing the tax rates on the main taxes, with the objective of stimulating foreign investment and allowing taxpayers to pay less tax so as to minimize evasion (Peci, 2010, p.46).

In this context, with 1st January 2009 changed only tax rates of main existing taxes, respectively has reduced tax rate of Corporate Income Tax (CIT) from $20 \%$ to $10 \%$, has reduced tax rate of Personal Income Tax (PIT) from 0\%, 5\%, 10\% and $20 \%$ to $0 \%, 4 \%, 8 \%$ and $10 \%$, which means that the highest rate of this tax will be $10 \%$ for taxpayers' and business activities. In contrast to above mentioned taxes, tax rate of VAT was increased from $15 \%$ to $16 \%$.

At CIT, designers had as an aim that through reduction of tax norm, to increase the competition capacity of Kosovo vis-à-vis foreign direct investments, respectively that CIT norm to be harmonized in the level of existing norms of CIT that were existing earlier in Balkan countries. At the case of PIT designers had as an aim achieving another objective; that of fighting fiscal evasion, respectively attracting tax subjects so that by stimulating with tax burden to move from subjects of grey economy to the subjects which reach to finish their tax obligations. In difference from two ahead mentioned forms, at the increase of VAT norm from 15\% to $16 \%$ designers had fiscal intentions, respectively the aim was to be done the compensation of public incomes that would be lacking along with decreasing of tax norms of CIT and PIT.

On 1 September 2015, the amendments to Law No. 05/L-029 on Corporate Income Tax, Law No. 05/L-037 on Value Added Tax and Law 05/L-028 on Personal Income Tax entered into force. The key elements of last reform are listed below. Deductible expenses to CIT now include:

- Job related training expenses incurred by an employer, without limitations;

- Contributions made for humanitarian, health, educational, religious, scientific, cultural, environmental and sports purposes, up to $10 \%$ of gross income before taxes; and

- $50 \%$ of representation costs, but not more than $1 \%$ of total gross income.

Based on the amendments, losses may be carried forward to be offset against future profits for 6 consecutive tax years (previously, 7 years).

Changes to VAT are listed below:

- The standard rate is $18 \%$ (previously, $16 \%$ );

- A reduced rate of $8 \%$ applies to the supply of: water, utilities, specific food products and medical equipment; and

- Taxable persons for VAT purposes are all individuals and legal entities making taxable supplies if their turnover exceeds EUR 30,000 within a calendar year (previously, EUR 50,000 in the previous 12 months).

Changes to Personal income tax are listed below:

Exempt income includes:

- Income from inheritance, if the heir is a spouse, child or parent of the deceased or if the value of inheritance does not exceed EUR 5,000; 
- Income received from grants, subsidies and donations; and

- Compensation received according to the final courts decisions.

The Kosovo tax system includes corporate income tax, personal income tax, withholding tax real estate tax, VAT, excise tax, and customs duties (Peci, 2009, p.222).

Following its declaration of independence, Kosovo has paid greater attention to tax treaties. In this regard the Office for Legal Issues, Treaties and Human Rights was established within the Ministry of External Affairs in 2008. This office deals with treaty issues regarding the elimination of double taxation.

Except decreasing of tax norms, Balkan countries have applied few numbers of tax incentives in order to simulate foreign investors which we will treat following.

\subsection{Tax Harmonization in Balkan Countries}

Although the term"tax system" makes us understand that the relations between the components constituting it have to be adjusted, practice shows that taxation in many countries is carried out by application of many tax instruments, each of which has its own objective and its own way of economic power inclusion. The taxation systems of contemporary countries differ a great deal or insignificantly between themselves and so two similar taxation systems cannot be found. That is why one cannot yet speak, for example, of a tax system of the developed countries of the Western Europe, of the taxation system of the EU member countries, etc., however it can be spoken about separate tax system of each country,for example of Germany, Belgium, Japan, etc. The taxation systems of modern countries differ as far as the constituting components are concerned, in the aspect of participation of some tax forms in the structure of public revenue of fiscal character, etc.

The changes in the tax structure of contemporary countries are conditioned by a series of factors, such as: economic development, socio-economic structure (respectively if it is a matter of market oriented economy or a centralized plan economy), the way of social security funding, the level of economy openness with abroad, the character of state structure (respectively if it is a complex or unitary state), affiliation to a certain international organization, tradition and historical development, etc.

Before we see the level to which the tax harmonization of the Balkan countries with the EU member countries has arrived, we have to clarify the notion "tax harmonization". The harmonization of taxes was treated differently by different authors in the theory of taxation (Prest, 1979, p.76). Not wishing to go to the scholastics of different definitions, we think that the clearest definition is the following: "tax harmonization is a process of elimination of tax obstacles and differences of the countries included in the EU” (IBFD, International Tax Glossary, 1996, p. 153).

In Europe the national frontiers have remained "a narrow framework" for the development of economic activities. We are witnesses of processes in which the economies of different countries are getting increasingly integrated through the interstate transfer of goods, capital, and technology. Such a tendency is particularly pointe out in some international economic associations, especially within the European Union member countries.

Harmonization of taxes is a process that aims at avoiding the national tax measures, which may have a negative impact on the common market functioning, on the circulation of people, goods, services, capital and competition. More concretely, the 1992 Agreement on the creation of the European Community (EEC) in section 3a is emphasized "its aim for creation of a common trade policy". The internal market of the European Community "will be characteristic for the avoidance of obstacles to the circulation of goods, people, services and capital between the member states" (EC Agreement, section 3a) and "it will be a system which ensures that the competition on the common market has not been broke" (Simon, 2000, p.269). Practice has shown that the creation of the common European market with the harmonization of tax systems would be an illusion. "The aim of the EU is to make the standardisation of national tax systems, but to influence on them being in accordance with the objectives of the Agreement of European Community. In this context the tax legislation of the European Community may be desirable (Goede, 2003, p. 204).

Since the national tax systems are in the jurisdictions of member states, it is difficult to reach complete harmonization of taxes by the EU member states. The joining of new states has deepened additionally the differences in the Union. Even after the application of the common market, there still does not exist in EU a real common tax policy.This has influenced the member states stand considering that the tax system is still the main symbol of state sovereignty and they convey reluctantly this competence of theirs to the Union.

However, there has been achieved a great deal so far in harmonization of taxes and tax systems of the EU member countries. The tax harmonization in application of some tax forms, such as customs and value added tax, makes possible an easier circulation of products, of capital and people. By the agreement on the establishment of the EU, legal standards have been determined on taxes, which produce legal effects to the EU member countries. According to these 
standards, all the member countries have the right to create their own tax systems and apply new tax forms, but observing the obligation to harmonize some parts of it (tax rates, tax basis, etc.) by EU decisions. The EU has promulgated some special executive decisions on harmonization of some taxes, so that a certain minimum of taxation systems harmonization has been created. Thus, there have been achievements in partial harmonization of indirect taxes, VAT and excises.

A legal basis for harmonization of indirect taxes is sections 90 to 93 of the Agreement on the Establishment of the EU. By these instructions (executive decisions) tax discrimination is forbidden, which directly or indirectly would be caused by national products to the detriment of national products of other member states (countries), so harmonization of turnover tax and excises, and other turnover taxes are attempted to reach. In this sense, the aims were achieved relatively fast, so that in 1970 in member countries multiphase turnover tax, which did not offer neutrality, was replaced by the value added tax. In this directive the Commission recommended to all the member states to implement value added taxation system in to their national tax systems as the system of indirect taxation. This step is considered as fulfilment of structural harmonization - the harmonization of indirect tax systems within the EU. During the harmonization efforts there have been several times suggested different tax bands for value added tax. In 1989 was for reduced rate suggested the band 4-9\% and for standard rate the band 14-20\% (Nerudova, 2004, p.137). Even though the harmonization has substantially eliminated the obstacles and market distortions in the area of indirect taxation - all member states are applying the same system of turnover taxation (value added tax system) and excise duties, in the area of direct taxation a great diversity of taxation systems still remains. The harmonization (or at least) coordination of corporate taxation together with increasing mobility of capital turned to be necessary in the process of market distortions and obstacles removal(Nerudova,2005,p.119). On the other hand, as far as the harmonization of direct taxes is concerned, the achievements are smaller and the income and profits tax is still imposed within the framework of national countries. In the field of profits tax of joint stock companies, the EU has two objectives: (1) avoiding the harmful (prejudicial) tax competition between the member countries, and (2) enabling the free capital turnover. Until 1997, the direct tax harmonization system in the EU was not a vast action. Before then only directives of company joining as mother-daughter companies had existed, which had been, first of all, oriented to regulation (arrangement) of issues related to double taxation. After 1997, the member countries started a vast treatment directed to an action that would control the tax competition negative effects. This action was aimed at harmonization of tax provisions in three fields: in taxation of enterprises, taxation of savings income and taxation of author's reimbursement between the enterprises. In order to increase the benefits resulting from the existence of the internal market, Societas Europaea was intended as the multinational type of the corporation which would eliminate the obstacles of the cross border business on the internal market. However even though the SE means the simplification in the area of company law, the problems connected with taxation still continue, because of the lack of common regulation and correct implementation. (Nerudova, 2005, p.119). Another progress was made in the field of corporate profits tax, where was done the harmonization of some issues related to the tax treatment of dividend payment between the companies and their statutory changes.

Joining the EU has been from the beginning the main motive for the Balkan countries, which influenced their taxation systems reformation as well, in accordance with the above- mentioned requirements requested by the EU. Today, when from the beginning of the transition process more than 26 years have passed, within the Balkan countries treated in this analysis, Bulgaria and Romania have been the most successful in reformation and harmonization of their tax systems. These countries have managed to build transparent, righteous (they have avoided differences in tax burdens), flexible and simple tax systems. Bulgaria and Romania joined the EU on 1 January 2007 (Lozev, 2007, p. 193-199). These two countries, with their tax reforms that they did before 1 January 2007, managed to harmonize to a quite great extent their tax systems with acquis communautaire (the integrity of EU laws produced so far). As far as the achievement of tax harmonization, Croatia come in the first line, and after it are placed Albania, Macedonia and Kosovo.

These countries are still in the process of balance between the direct and indirect taxes and creation of a taxation system, which would have a neutral stand against the competition in the internal national market economy. The deadlock in this harmonization is the result of differences in levying the income and public expenses structures, economic challenges, administrative capabilities, etc. These differences make these Balkan countries to have different systems and policies from the EU ones.

The nearest prospects in these countries are in harmonization of customs tax policies. Such a thing would be achieved by gradual reduction of customs duties until their complete removal, the way the European Union did. The great efforts are to be made in the future for harmonization of tax systems of these countries with the EU.

Although it has a simple legislation, Kosovo has still to do a great deal in the function of fulfillment of legal gaps, tax harmonization with the EU and regulation of international tax relations aiming at eliminating double taxation. The measures undertaken by Kosovo to eliminate double taxation are unilateral and international. Kosovo, as the newest 
country internationally recognized by 107 countries, is in the process of creating the framework for elimination of double taxation. The legal framework for the elimination of double taxation has started by the UNMIK. Taking into consideration the specific political status of Kosovo until the declaration of independence, the process for the establishing the unilateral and international legal framework has been deficient, slow and with delays.

For eight and a half years (1999-2008), respectively for the duration of the interim administration, there prevailed unilateral measures for elimination of double taxation.

Unilateral measures to eliminate double taxation are based on domestic laws that follow the principles contained in the OECD Model Tax Convention (OECD Model).Because the Kosovo does not have an established comprehensive tax treaty network, the ordinary credit method is applied in order to eliminate from double taxation. Thus, in the absence of a tax treaty, unilateral relief is granted in the form of an ordinary tax credit for income taxes paid abroad. The credit is limited to the lower of the foreign tax and that part of the Kosovo tax which is attributable to the income that has been taxed abroad. A non-resident person with a Permanent Establishment in Kosovo can obtain an official document from the Kosovo tax administration certifying the amount of taxes they have paid, which can be used to obtain a credit abroad (Peci, 2010, p. 46).

During the UNMIK administration (1999-2008), the Kosovo authorities did not take an official position regarding the tax treaties signed by the former Yugoslavia. Unofficially, however, they did not recognize these tax treaties.

The former Yugoslavia signed tax treaties with 20 countries between 1975 and 1990 as follows: France (1975), Sweden (1981), Denmark (1981), Belgium (1981), the United Kingdom (1982), the Netherlands (1982), Czechoslovakia (1982), Italy (1983), Poland (1983), Norway (1985), Cyprus (1986), Sri Lanka (1986), Finland (1987), Romania (1987), Hungary (1987), Germany (1988), Egypt (1988), China (1989), the Philippines (1990) and Malaysia (1990). Given the significant socio-economic changes that have occurred since these treaties were signed, as well as changes in tax legislation, the existing treaties clearly need to be revised or renegotiated (Peci, 2010, p.45). During the UNMIK administration, Kosovo has entered into a tax treaty with Albania, which is effective from 1 January 2006. No other tax treaties have been concluded by the UNMIK administration.

Following its declaration of independence in 2008, Kosovo has paid greater attention to tax treaties. In this regard the Office for Legal Issues, Treaties and Human Rights was established within the Ministry of External Affairs in 2008. This office deals with treaty issues regarding the elimination of double taxation. After declaration of independence, Kosovo and several European countries have enacted several agreements signed by the former Yugoslavia. The president of Kosovo has signed the respective decrees for the approval of these agreements, including double taxation treaties. Thus far, Kosovo has ratified five such tax treaties, those with Belgium, United Kingdom, Germany, the Netherlands and Finland. (Peci,2015,p.20). The treaties signed by the former Federal Republic of Yugoslavia are, however, not recognized as applicable by Kosovo (Kosovo Declaration of Independence, 17 February 2008).

\section{Conclusions}

Each Balkan country has gone, from the start of the transition process in the 90s to the present day, in the process of tax reforms, through a special path differently in different countries, bearing on it certain features. However, the trend of reforms and objectives for joining the EU were and remains common. In this context, all the Balkan countries applied in different years their tax systems, VAT, the corporate income tax, personal income tax.

In the process of tax systems reformation, there are two trends, in addition to others, to be distinguished: 1) The trend of reducing tax rates of the main taxes, with special emphasis on corporate income tax, and 2) The aspiration and actions of all the Balkan countries for joining the EU by adopting the EU rules. Some of the selected countries in this analysis have managed to even become members of the EU, such as Bulgaria, Romania and Croatia. Others have still a road to make.

The tax system and policy, built by UNMIK, had only fiscal purposes. UNMIK created this policy: 1) not in accordance with the specificities of the economic development of Kosovo, 2) in the absence of a strategy of the economic development of Kosovo, 3) in the absence of the political status settlement, and 4) in the absence of real recognition of the main macroeconomic indicators, whose recognition is a conditio sine qua non for a sustainable fiscal policy. Based on such a situation, the tax system and policies had only fiscal functions with a very high participation of indirect border taxes in the total tax income.

Therefore, surpass these challenges we think that the following measures are to be applied: Firstly, there ought to be create a long-term development strategy of Kosovo and, in accordance with it, a long-term and sustainable fiscal policy ought to be formulated.

Secondly, an internal taxation system ought to be created, so that from direct taxes and internal VAT larger income could be collected, so that the tax burden could be transferred from the border to the inner land. This is due to the fact that the 
state, which builds its taxation system only on indirect taxes, burdens the export of its products, as their competitive capability will be poorer in the external market in relation to the products of a country in which a balance between the direct and indirect taxes exists. In the case of export, its production price is lower, as it is burdened with the turnover tax as an integral part of the price of the products. The achievement of the balance between direct and indirect taxes would enable for the tax system of Kosovo to have a neutral effect against the competition and at the same time the request for financial funds and for financing the social needs would be accomplished. Parallel to this, there ought to be reduction to maximum or complete removal of the fiscal burden (customs, excises and VAT) on the imported goods in Kosovo, which serve as a raw material for the resident and foreign investors. Tax facilities to stimulate foreign and internal investments would urge the economic development, which is an essential condition for a later growth of fiscal capacities of the taxation system of Kosovo.

Thirdly, there ought to be established unified, modern, professional and efficient tax administration services, which are essential conditions for a successful application of the tax system and policies in Kosovo. The taxation system can be efficient only if a successful implementation of the tax rules and legal enactments by the tax administration, as well as the identification of taxpayers, are ensured. In the context of the accomplishment of these objectives, the Ministry of Economy and Finances ought to accelerate its efforts for perfection, respectively for the perfection of tax administration in accordance with the recommendations of the International Monetary Fund.

Fourthly, it has to be formed a task force of experts on the highest level, for the purpose of initial codification of the positive tax law and harmonization and adoption of EU laws with Kosovo, as much as the specificities of the economic development of Kosovo allow such a thing.

\section{References}

Albania-Country Key Features, IBFD. (2016). http://online.ibfd.org/document/kf_al

Bedri, P. (2009). The Kosovo Tax System, European Taxation Journal, 49(4), 222-224.

Bedri, P. (2010). Relief from Double Taxation in Kosovo, European Taxation Journal, 50(1), 44-46.

Bedri, P. (2011). Tax Incentives as Important Segment of Tax Reforms in Balkan Countries and Kosovo, Academic Journal -Yearbook Faculty of Law of University of Sarajevo, 54, 245-269.

Bedri, P. (2013). Reform of Kosovo Tax System after Independence and its key functions", Illyria International Review, 69-85.

Bedri, P. (2015). Overview of Major Issues of Tax Treaties Law in Kosovo, AUDE, 11(3), 15-23. http://journals.univ-danubius.ro/index.php/oeconomica/article/view/2757/2427

Brun. (2005). LIII(6), 119-128. http://dx.doi.org/10.11118/actaun200553060119

Bulgaria-Country Key Features, IBFD.(2016). http://online.ibfd.org/document/kf_bg

Casanegra de, J. M., Silvani, C., \& Vehorn, C. L. (1992). Modernizing Tax Administration. In: Tanzi, Vito (eds.), Fiscal Policies in Economies in Transition.Washington, D.C.: International Monetary Fund.

Croatia-County Key Features, IBFD.(2016). Retrieved from http://online.ibfd.org/document/kf_hr

Dabrowski, M., \& Radziwill, A. (2005). International Public Goods for Economic Development: the Case of Post-Communist Transition" Weatherhead Center for International Affairs, Harvard University, 1-27. http://www.case-research.eu/sites/default/files/1_3.pdf

Fischer, S., \& Ratna, S. (2001). The Transition Economies after Ten Years, in:Orlowski, Lucjan T. (ed.) Transition and Growth in Post-communist Countries: The Ten-year Experience, Cheltenham, UK and Northampton, MA, USA: Edward Elgar, 3-47.

GoedeDe, J. (2003). European Integration and Tax Law, IBDF, Amsterdam, 43(6).

Grabowski, M., Tomalak, M. (2004). Tax system Reforms in the Countries of the Central Europe and the CIS”, Special Study, pp.251-301, Retrieved from http://www.warsawvoice.pl/krynica2004/special\%20study.pdf

IBFD. (1996). International Tax Glossary, revised 3rd ed. Amsterdam: International Bureau of Fiscal Docummentation.

IMF.(2009). Aide Memoire, of the IMF Staff Mission to Kosovo, Index of Economic Freedom, February 2009. Kosovo-Country Key Features IBFD, http://online.ibfd.org/document/kf_k1

Lozev, K. (2007). EU Accession and The Bulgarian Tax System, IBFD, Amsterdam, European Taxation. Macedonia (FYR) - Country Key Features, IBFD. (2016). http://online.ibfd.org/document/kf_mk

Montenegro - Country Key Features IBFD.(2016). http://online.ibfd.org/document/kf_me

Nerudova, D. (2004). Tax competition and tax harmonization in the European Union. Acta univ. agric et silvic. Mendel. 
Brun., 6, 135-144. http://dx.doi.org/10.11118/actaun200452060135

Nerudová, D. Societas Europaea - tax and legal aspects. Acta univ. agric. et silvic. Mendel.

Prest, A. (1979). "Fiscal Policy", in Economic Policies of the Common Market,.ed. P. Coffey: Macmillan, London. Romania - Country Key Features IBFD . http://online.ibfd.org/document/kf_ro.

Rigger, N. (2000). Central and Eastern Europe and the New Financial Architecture, Finance and Development, Washington (IMF), 37(3), 1-6.

Sergi, S. B. (2005). The Balkans Jump on the tax Rivalry Bandwagon", SEER-South-East Europe Review for Labour and Social Affairs, Brussels, 1, 7-18. www.ceeol.com.16.06.2016.

Simon, J. (2000). Can We Harmonise Our Views on European Tax Harmonization?, Bulletin for International Fiscal Documentation, 54(6), 263-269. Serbia - Key Country Key Features, IBFD. http://online.ibfd.org/document/kf_rs,

Tanzi, V. (1993).Transition to Market - Studies in Fiscal Reform.

Tanzi, V. (2002). Fiscal Policies in Economies in Transition.

UNMIK at a Glance. (2007) http:// www.unmikonline.org/intro.h Bulgaria-Country Key Features IBFD. http://online.ibfd.org/document/kf_bg

\section{(c) $\mathbf{E Y}$}

This work is licensed under a Creative Commons Attribution 3.0 License. 